\title{
Phoney war psychology
}

\author{
Louis APPLEBY, Senior Lecturer, University Department of Psychiatry, Withington \\ Hospital, Manchester M20 8LR
}

One curious image of the earliest Gulf fighting was a TV journalist standing in front of an acre of rubble in Tel Aviv and insisting, "The main effect of this Scud attack was psychological". What made it more curious was that after what had gone before, it was easy to believe him. Because, deprived of substantial news by a lack of action and the censorship of both sides, journalists had for weeks presented a procession of "psychological" angles, although they were more a clue to what the word means to the press.

'Newsnight' devoted much of one evening to the psychological battle which mainly consisted of crude broadcasts beamed from one army to the other. The Iraqis employed a woman, inevitably nicknamed Baghdad Betty, to inform American soldiers that back home their wives were sleeping with film stars. It wasn't clear what the Americans were transmitting in reply except suggestions that the Iraqis should desert, but shots of a past triumph reminded us of what they could achieve - when General Noriega, sheltering in Panama's Vatican Embassy, was forced out by a relentless assault with David Bowie music.

According to George Orwell, the most successful measure of this kind during the Spanish Civil War was the work of a militiaman who used to shout, "We're eating buttered toast" to the Fascist line, thus encouraging a steady stream of desertion. So it can work, but is it psychology?

The explicit target of such transparent lies is troop morale, an entity which itself was much mentioned by a seemingly endless parade of former army brass. There is no doubt that morale has a powerful influence on action - William Shawcross has attributed the barbarism of the Khmer Rouge to the crushing their morale suffered during the bombing of Cambodia. The news from the Gulf made it clear that Iraqi morale could be weakened by Allied bombardment while Allied morale was undermined (not the same as weakened) by anti-war protesters and delays in starting the fight.

Which makes sense as far as it goes, though that is not far. We had to wait a long time to find anyone who would go beyond morale's movements up or down to ask what it was made of and precisely how it changed. What, after all, is morale? It was left to the American writer P. J. O'Rourke to offer a definition. Morale, he wrote in the Observer, is how well a person is doing when he is not doing well at all.

For something less whimsical, we had to rely on the servicemen themselves. In what could have been the most penetrating of interviews, a Tornado pilot who had just returned from his first action was asked the obligatory psychological question: how does it feel? "It's absolutely terrifying," he admitted. "You're afraid of failure and you're afraid of dying." Failure as well as dying and in that order. Here was a window on the meaning of morale and an invitation to something genuinely psychological. But the reporter was satisfied with the news that facing anti-aircraft fire was frightening and the window closed.

This genre is sometimes given the dreary label of "psychologising the issues" but it too often means disguising the obvious as a mental insight. To some extent the problem is psychology itself. When its conclusions run with intuition, as they often do, they can be dismissed as obvious. When they don't, they can be dismissed as implausible. But the blame really belongs to the belief common in the media that the purpose of psychology is to uncover instincts and reveal the unconscious, a belief psychiatrists and psychologists are sometimes slow to challenge.

As a result, media psychology is often not concerned with the mind, or rather the conscious mind. A psychologised issue is not one whose cognitive intricacies have been dissected, it is one that has been reduced to a raw emotion or a primitive piece of Freudianism. So the psychology of the phoney war was about nothing more sophisticated than being afraid or annoying the opposition.

In Annie Hall, Woody Allen asks his wife, "Why must you reduce my animal urges to psychoanalytic concepts?" Those first Gulf reports showed what he meant. 